\title{
On Translation of Children's Literature: Characters of Children's Books Enjoy a Different Diet in Iran
}

\author{
Bita Naghmeh-abbaspour*; Tengku Sepora Tengku Mahadi \\ School of Languages, Literacies and Translation, Universiti Sains Malaysia (USM)
}

Email: bita_ab53@yahoo.com

\begin{abstract}
Undoubtedly the difficulty of translating culture-bound elements will be be much more challenging when the audience are children who do not have any perspective on cultural diversity of different nations. The culture-bound elements can be consists of a wide range of elements, i.e. proper names, religion terms, food and drink items and so on. Dealing with each of these items will be a real challenge when translators have this perception that most probably their audiences do not have any idea about the in hand culturebound element, and it will be their choice to present the new items to the child reader or replace it with a familiar one. With this perspective, the present textual analysis study, aims to explore the lexical choices that translator's of children's literature in Iran made, facing such elements. The present effort restricts itself to the 'food and drink' items and illustrates the way that Persian translators approach these culturebound elements in a 70 years period and discusses their lexical choices following the socio-cultural norms of the time.
\end{abstract}

KeyWords: Translated Children's Literature, Culture-Bound Elements, Norms, Domestication, Foreignization

\section{Introduction}

The main objectives of this textual analysis paper are first to illustrate the effect of translated literature on forming the child's worldview toward the other cultures and emphasis on the translator's subtle duty to form an authentic perspective over the cultural diversity of this global village. Accordingly the paper will be divided into three sections. The first section elaborates the theoretical perspectives of translating children's literature, the second section discusses the collected data and analysis and finally the third section concludes with a discussion on the challenges of the research.

This is not deniable that children's literature translated from different cultures are bright windows open in front of youngsters to show them the colorful diversity of cultures all around the world. In fact through stories children gain new perspectives toward the other people, cultures and new sets of experiences. 


\section{Children Literature and Translation}

Before proceeding to the theoretical part we need to know translated children's literature in nature. In fact providing a clear definition for children's literature is not an easy task to do. The challenging and vague nature of children's literature is deeply rooted in its multi-functionality and the variety of cultural restrictions and limitations that this genre operates under. It seems that very broad definition that Knowles and Malmkjear (1996) offered for children's literature, eluded the difficult issues of this area, "For us children's literature is any narrative written or published for children and we include the 'teen' novels aimed at the 'young adult' or ' late adolescent' reader" (Cites in lathey 2006, p. 16). However Oittinen with a more straightforward definition indicated the difficulty presented in this genre:

"There is little consensus on the definition of child, childhood and children's literature. The definition .... is always a question of point of view and situation: childhood can be considered a social or cultural issue, it can be seen from the child's or adult's angle ... I see children's literature as literature read silent by children and aloud to children" (Oittinen, 2000, p: 11)

Peter Hunt pointed out that the relation of Children and books "lies behind the connection between literature and literacy, whether or not children's book are seen as valuable in themselves, or as steppingstones to higher things (to 'adult' or 'great' literature) (Hunt, 2005, p. 3). However to Shavit children's literature has the tendency to remain uneconomical and culturally marginalized particularly because of its minority child audience and their literature that is not considered as central to 'high art' and culture (Cited in Lathey, 2006, p. 18).

When the original children's literature has a peripheral position in the literary system, what should be the vision for translated of children's literature? With no surprise we realize that not only this genre has a marginal position in the literary system, but suffers the same status in the field of translation study as well. Indeed the traditional study of translation barely considered children's literature as high art sitting in the center. As Katharina Reiss notices: "for centuries critics have been concerned with both the theory and practice of the complicated and complex phenomenon of translation but scarcely any thing has been said about the translation of books for children and young people" (Reiss, Cited in NaghmehAbbaspour, 2012). Reiss made a serious study at the subject and tried to identify the specific problems of translation of children's literature in the context of her typology of texts. And indicated three different factors, which justify why translated children's literature demands a special kind of study:

1. The ...asymmetry of the entire translation process: ... adults are translating works written by adults for children and young people.

2. The agency of intermediaries who exert pressure on the translator to observe taboos or follow educational principles.

3. Children's and young people's (still) limited knowledge of the world and experience of life. (Ibid)

Respecting Reiss's typology, and her emphasis of children's (still) limited knowledge and experience of the world, how should adult translators or filtering agencies approach the new cultural elements of the source text? Should they ban all the new culture bound elements and let children to live with their familiar experiences, or should open the colorful windows of cultural diversity to children minds, and let them experience the world through translations. However children's books in any stage need adults' confirmation. Children are consumers of the literature that adults produce for them, however it is not the final point and the situation becomes more complicated in case of translation of children's literature. As 
Oittinen explained, "Even though translators need to translate for children, it is the adults who select the books that need to be translated; it is the adults who translate them and buy the translations for children. It is also the adults who usually read the books aloud." (Oittinen, 2006, P. 36).

More over translations of children's literature, serve numerous goals in different socio-cultural environments. Accordingly Hans J. Vermeer's skopos theory can help the translator of the children's literature. Vermeer discussed that every act of translating has a specific purpose (i.e. skopos), and all translations should be domesticated respecting this skopos (Munday, 2012, p. 122). The same is true in translating of children's literature. According the Vermeer the role of 'client' is very important in the skopos of the translation and the translator should be loyal to his/her client. However in the genre of children's literature, the client is not that clear. In fact the translators of children's literature are not sure that are they translating for child readers, for publishers of children literature, or for the parents?

\section{Culture-Bound Elements}

Reflecting on cultural functions of the literature, can clarify the important role of translators dealing with culture-bound elements of the source language into the target language. Bassnett (2014) defined the language as the heart in the body of culture. This way the language through translation has the ability to express the values of its own culture into other languages. However any sort of distortions that translator do in terms of universality can cause a problem. To Nida (Cited in Naghmehabbaspour, 2013) "Most cultural words are easy to detect, since they are associated with a particular language and can not be literally translated". Translating of the culture bound elements such as food items looks really problematic especially due to the complexity of cultural patterns. According to Aixela (1996) because of their cultural or historical associations, the culture bound elements are normally tied in such a dense signifiers that translating them need to deal with loads of information conveying them. In case of children's literature translators should be very cautious not to overload the information, as the huge load of information may distract the child readers from the main plot of the story that author wanted them to follow. Obviously, respecting the always-remaining differences between languages and cultures, the act of translation can never be innocent, however translators should avoid the unnecessary manipulations (Lefevere ,1992).

Respecting all noted above, this paper aims to perform a chronological comparative textual study on translation of children's literature in Iran and examine the strategies that translators applied in 7 decades facing new cultural terms. Therefore it approaches the lexical choices in translation of children's literature in the light of Schleiremacher model that later on rephrased by Venuti.

\section{Schleiermacher Model}

Friedrich Schleiremacher in a lecture titled 'On the different ways of translating', emphasized on that considering all characters of translations from different languages, it is vital for a translation to be read and sound different. According to Schleiremacher "the reader should be able to guess the Spanish behind a translation from Spanish, and the Greek behind a translation from Greek. If all translations read and sound alike, the identity of the source text has been lost, leveled in the target text" (cited in Bassnett \& Lefevere, 1998, p. 8). By applying this strategy, the privileged position of target language or culture will be fade and the otherness of the source culture will be preserved (ibid). Schleiermacher moves beyond the strict issues of literal, free or faithful translation and stated that there are only two paths open in front of the 'true' translator: "Either the translator leaves the write in peace as much as possible and moves the reader toward him, or he leaves the reader in peace as much as possible and moves the writer toward him" (Schleiemacher, Cited in Munday 2012, p. 46). Schlieremacher himself preferred the strategy that moves the reader towards the writer; that he called it 'alienating' method. The other method that Schleiermacher 
introduced was 'naturalizing' that means bringing the foreign text in line with typical patterns of the target language. More recently Lawrence Venuti, an American theorist, followed Schliermacher's approach and rephrase Schlieremacher's methods as Foreignization and domestication (Munday, 2012, pp. 46-7). Like Schleiermacher, the preferred strategy of Venuti is foreinization (alienating), he mentioneded several reasons of desirability of foreignization and rejecting domestication. To Venuti domestication was ethnocentric racism and violence strategy, which may only be attacked by challenging the dominant aesthetics and foreignizing texts and shows how invisibility of translator is hand in hand with these two types of translating strategy. He defines domestication as a strategy, which involves downplaying the foreign characteristics of the language and culture of ST. This strategy is opposed to the foreignization. Venuti also emphasizes that; he himself prefers the latter one and calls it a "Highly desirable" strategy (Venuti, 1995, pp.19- 20).

\section{Sample}

Offering a better perspective of the level of domestication (naturalizing) approach of translators of children's literature in different eras, the paper provides 10 extracts of translated children literature. In each of these examples at least one culture-bound unit is domesticated. Though they are presented into textual extracts, units of the study are generally the single words standing for food items or drinks. The extracts are collected from different translations of two classic children's books of Alice's adventures in wonderland, and Grimm Brothers' Fairy Tales. As a comparative study the paper reviews the strategies of translators of children literature in a 70 years period, between mid 1920s and mid 2000s to obtain a better perspective of the norms of the time. And see how diverse the literary place and function of translated children literature was in mid 1920s from what it is today.

In order to facilitate comparing the culture-bound units, the Persian and English extracts are presented in tables and the problematic units are bolded to make them easier to find. Above each item the name of translator and the year of publishing is stated. Each box will be followed by a short analysis of domesticated lexical choice(s). One of the classic translations of Alice's adventures in Wonderland, which was published in a children magazine called 'Ettelaat e Koodakan' (kids' information), has no translator's name accompanied. Thus here just the name of the magazine is mentioned and not translator.

\section{Data Analysis}

As indicated above the focus of this textual analysis paper is particularly on translation of food and drink items. This section presents a few examples to illustrate how chronologically translation of culture-bound elements affected by variety of translator's strategies. The analysis of each example will follow it. 


\section{Example 1}

(Alice's Adventures in Wonderland)

\begin{tabular}{|c|c|c|c|}
\hline Original & $\begin{array}{c}\text { Honarmandi } \\
\text { (1928) }\end{array}$ & $\begin{array}{c}\text { Etelaate koodakan } \\
\text { (1956) }\end{array}$ & Pirzad (1996) \\
\hline $\begin{array}{l}\text { It was labeled } \\
\text { "ORANGE } \\
\text { MARMALADE", }\end{array}$ & رويش نوشته بود : لرزانك & 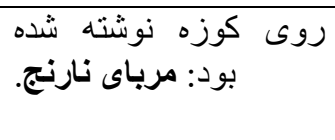 & 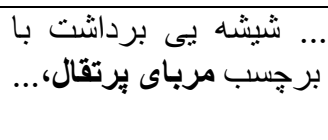 \\
\hline
\end{tabular}

Honarmandi (1920) replaced 'marmalade' with 'jelly', although /Moraba/ is a proper Persian equivalence of marmalade. It seems that Honarmandi was not sure about the concept of Marmalade, while the other above mentioned translators, chose the right equivalence, /Moraba/.

\section{Example 2}

(Alice's Adventures in Wonderland)

\begin{tabular}{|c|c|c|c|}
\hline Original & $\begin{array}{c}\text { Honarmandi } \\
\text { (1928) }\end{array}$ & $\begin{array}{l}\text { Ettelaat e koodakan } \\
\qquad(1956)\end{array}$ & $\begin{array}{l}\text { Pirzad } \\
(1996)\end{array}$ \\
\hline $\begin{array}{l}\text { It had in fact, a sort } \\
\text { of mixed flavor of } \\
\text { cherry-tart, } \\
\text { custard, pine-apple, } \\
\text { roast turkey, toffee } \\
\text { and hot buttered } \\
\text { toast. }\end{array}$ & 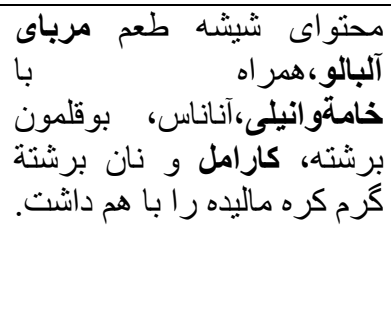 & 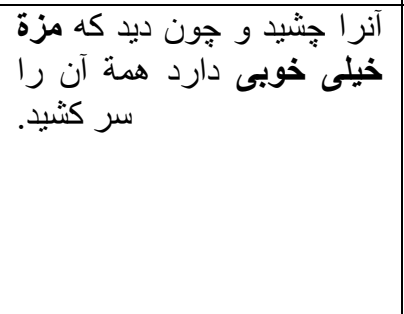 & 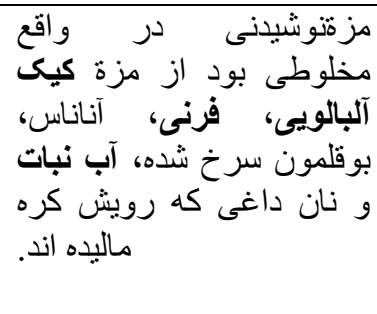 \\
\hline
\end{tabular}

This is a controversial example, as there are different replacements and misrepresentations of food items. First of all Honarmandi (1928) used /Moraba/ (Marmalade/Jam) instead of Tart (which is a kind of cake covered with fruit jam), and simply converted it to 'Cherry Marmalade'. However Pirzad (1996) rendered it into 'Cherry Cake', which is almost close although is not a tart. Moreover in case of 'Custard', which has no specific equivalence in Farsi, Honarmadi (1928) replaced it with 'Vanilla Cream', that do not convey any special senses except just a bowl of cream flavored with vanilla. Pirzad (1996) replaced Custard with a traditional Persian dessert. The last item in this example is Toffee that Honarmandi (1928) translated it into Caramel while sixty years later Pirzad (1996) converted it into /Abnabat/ (candy). Amazingly, translator of Ettelaat e koodakan, did not challenge him/herself and instead mentioning of all food items above, stated that 'It had a very good taste'. 


\section{Example 3}

(Alice's Adventures in Wonderland)

\begin{tabular}{|c|c|c|c|}
\hline Original & $\begin{array}{l}\text { Honarmandi } \\
\text { (1928) }\end{array}$ & $\begin{array}{l}\text { Ettelaat e koodakan } \\
\text { (1956) }\end{array}$ & $\begin{array}{l}\text { Pirzad } \\
\text { (1996) }\end{array}$ \\
\hline $\begin{array}{l}\text { She opened it, and } \\
\text { found in it a very } \\
\text { small cake, on } \\
\text { which the words } \\
\text { "EAT ME" were } \\
\text { beautifully marked } \\
\text { in currants. }\end{array}$ & 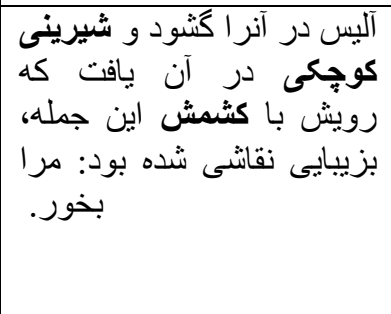 & 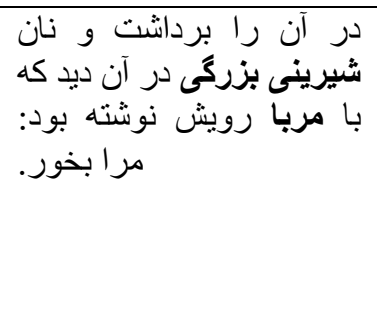 & 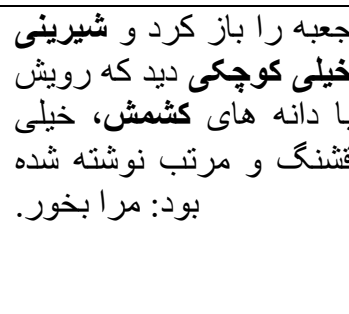 \\
\hline
\end{tabular}

First of all, all three Persian translators generalized the term Cake to Sweet that in Persian language covers a wider conceptual level rather than cake. Besides as Persian language borrowed the term Cake from English with the same pronunciation, lacating it into a more general level do not have any sense.

Also in translation of Ettelaat e koodakan (1956) currant is converted as Marmalade, which again seems an unnecessary conversion. Perhaps the translator considers it more usual to decorate sweets with jam rather than currents, and simply tried to create a more natural picture in kids mind.

\section{Example 4}

(Alice's Adventures in Wonderland)

\begin{tabular}{|c|c|c|c|}
\hline Original & $\begin{array}{c}\text { Honarmandi } \\
\text { (1928) }\end{array}$ & $\begin{array}{c}\text { Ettelaat e koodakan } \\
\text { (1956) }\end{array}$ & $\begin{array}{l}\text { Pirzad } \\
(1996)\end{array}$ \\
\hline $\begin{array}{l}\text { Pebbles were all } \\
\text { turning into little } \\
\text { cakes as they lay } \\
\text { on the floor. }\end{array}$ & به ناتهريزى هـاى كفى كوجى اتاق هدل & سنح ريزه ها همان تبديل به شئد. & اتاق تبديله ها تا مى شى شنتد كف به \\
\hline
\end{tabular}

In above example Honarmandi (1928), converted 'little cakes' into 'small pieces of sweet bread', while Ettelaat e Koodakan(1956) and Pirzad (1996) both chose just the term 'sweets' which as explained in example 4, is a sort of generalization. Although all items have a sweet taste, the conceptualization of translations is different from the Original item. 


\section{Example 5}

(Alice's Adventures in Wonderland)

\begin{tabular}{|c|c|c|c|}
\hline Original & $\begin{array}{l}\text { Honarmandi } \\
\text { (1928) }\end{array}$ & $\begin{array}{l}\text { Ettelaat e koodakan } \\
\qquad(1965)\end{array}$ & $\begin{array}{l}\text { Pirzad } \\
(1996)\end{array}$ \\
\hline $\begin{array}{l}\text { "Have some wine," } \\
\text { the March Hare } \\
\text { said in an } \\
\text { encouraging tone. }\end{array}$ & خَّتُش: آيا نوشابه لحن ميل داريد؟ مهرى & Deleted Unit & خركوش تعارف كرد: بفرماييد. \\
\hline
\end{tabular}

Honarmandi's translated the term Wine into Soda. This choise could be due to both cultural and religious condsiderations. As not only Wine is forbidden in Islamic tradition, but also considering the child audience and following the Persian cultural norms, normally the name of alcoholic drinks is not allowed to be mentioned in children's books. However, after passing sixty years we can see that Pirzad (1996) kept the Wine term /Sharab/ in his translation.

Ettelaat e Koodakan (1965), same as the pervious examples, kept the safe side and simply deleted the term Wine.

\section{Example 6}

(Alice's Adventures in Wonderland)

\begin{tabular}{|c|c|c|c|}
\hline Original & $\begin{array}{c}\text { Honarmandi } \\
\text { (1928) }\end{array}$ & $\begin{array}{c}\text { Ettelaat e koodakan } \\
\text { (1956) }\end{array}$ & $\begin{array}{l}\text { Pirzad } \\
(1996)\end{array}$ \\
\hline $\begin{array}{l}\text { "I passed by his } \\
\text { garden, and } \\
\text { marked, with one } \\
\text { eye, how the owl } \\
\text { and the oyster } \\
\text { were sharing a } \\
\text { pie." }\end{array}$ & 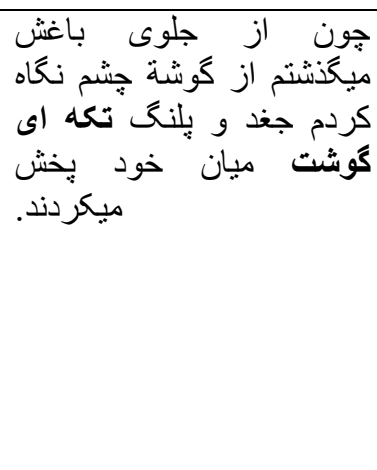 & Deleted Unit & 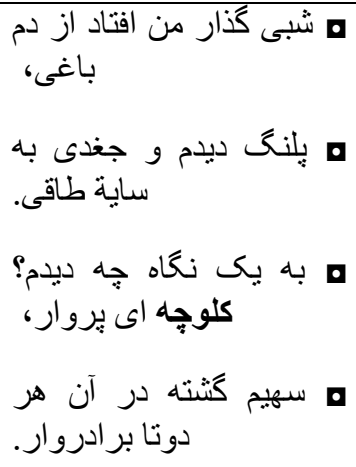 \\
\hline
\end{tabular}

Each of thee Persian translators approached Pie (sort of baked dish of meat or fruit that is covered with pastry) differently. Honarmandi (1928) translated it as ' apiece of meat', Pirzad (1996) chose 'Cookie' as the equivalence of Pie, and Ettelaat e Koodakan, did not bother and just deleted the food item. 


\section{Example 7}

(Alice's Adventures in Wonderland)

\begin{tabular}{|c|c|c|c|}
\hline Original & $\begin{array}{c}\text { Honarmandi } \\
\text { (1928) }\end{array}$ & $\begin{array}{c}\text { Etelaat e koodakan } \\
\text { (1956) }\end{array}$ & $\begin{array}{l}\text { Pirzad } \\
(1996)\end{array}$ \\
\hline Who stole the tarts? & نانهاى قتدى را كه دزديد؟ & Deleted Unit & شيريني ها را كى دزديد؟ \\
\hline
\end{tabular}

At this point translators tried to domesticate, Tart, by converting it in a wider category. Here both translators escaped from a foreign food item.

\section{Example 8}

(Grimm Brothers' Fairy Tales: Hansel and Gretel)

\begin{tabular}{|c|c|c|}
\hline Grimm Brothers & $\begin{array}{l}\text { Mosaheb } \\
\text { (1956) }\end{array}$ & $\begin{array}{c}\text { Panjeshahi } \\
\text { (2006) }\end{array}$ \\
\hline $\begin{array}{l}\text { She took them both } \\
\text { by the hand and led } \\
\text { them into her } \\
\text { cottage. A good } \\
\text { meal of milk and } \\
\text { pancakes with } \\
\text { sugar, apples, and } \\
\text { nuts, was spread on } \\
\text { the table. }\end{array}$ & 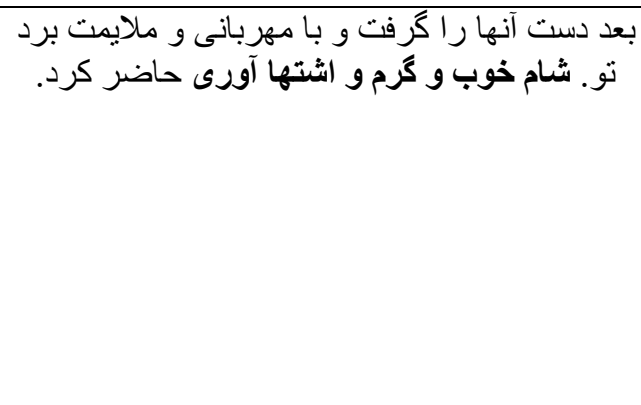 & 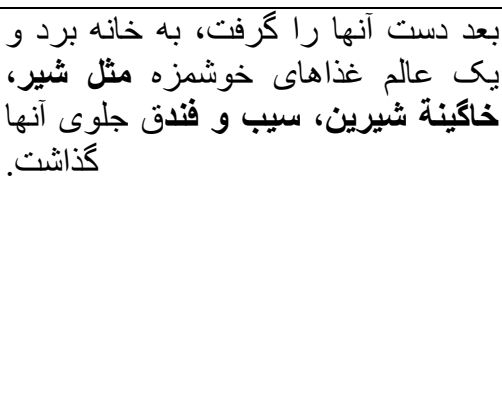 \\
\hline
\end{tabular}

Mosaheb (1956) did not bother herself to challenge with a culture-bound term and deleted the new term 'Pancake' and replaced the whole different kinds of food with 'a nice and tasty dinner', with no more specification.

On the other hand, Panjehshahi (2006), did her best to find a more tangible equivalence for the Pancake in Persian language and she swapped it with /Khagineh/ a traditional Persian cuisine, more or less like scrambled-egg that normally seasoned by salt. Except having eggs, there is no similarity between /Khagineh/ and 'pancake with sugar'. 


\section{Example 9}

(Grimm Brothers' Fairy Tales: Catherine and Frederick)

\begin{tabular}{|c|c|c|}
\hline Grimm Brothers & $\begin{array}{l}\text { Mosaheb } \\
\text { (1956) }\end{array}$ & $\begin{array}{c}\text { Panjeshahi } \\
(2006)\end{array}$ \\
\hline $\begin{array}{l}\text { As dinner-time } \\
\text { approach, she took } \\
\text { down a sausage out } \\
\text { of the chimney, and } \\
\text { putting it in a frying } \\
\text { - pan with butter. }\end{array}$ & طرف عصر ليلا به تهية طاس كباب مشغول شد & 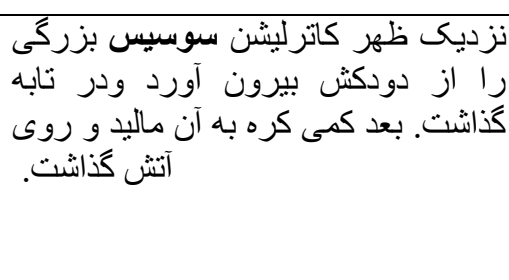 \\
\hline
\end{tabular}

In this table, Mosaheb, Domesticated Sausage into طاس كباب, to escape from using foreign food item.

\section{Example 10}

(Grimm Brothers' Fairy Tales: Catherine and Frederick)

\begin{tabular}{|c|c|c|}
\hline Grimm Brothers & $\begin{array}{l}\text { Mosaheb } \\
\text { (1956) }\end{array}$ & $\begin{array}{c}\text { Panjeshahi } \\
\text { (2006) }\end{array}$ \\
\hline $\begin{array}{l}\text {... while the sausage } \\
\text { was getting ready } \\
\text { she might go into the } \\
\text { cellar and draw } \\
\text { some beer. }\end{array}$ & 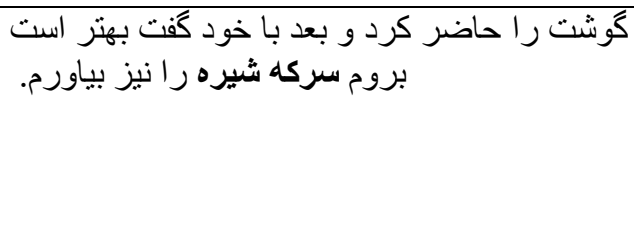 & ناكَان فوسيس سرى به نظرش ميشود، رسيد: بروم و از زير \\
\hline
\end{tabular}

Again Beer as an alcoholic drink considered inappropriate for being part of children's literature either culturally or ideologically. Therefore, Mosaheb (1956) changed it to /Serke Shire/ a very traditional drink of Persian people. However Panjeshiri (2006) generalized the term Beer into a 'cold drink'.

\section{Conclusion}

Different Food items are representations of different cultures, therefore as saving the original term in translation can be seen a respectful manner toward the original cultures, replacing them with the target items can represent a symbol of violence in translation. Indeed depending on the translators' choice of global (foreignization) or local (domestication) strategies, the translation of children's literature, can be a means of obscuring cultural differences or bridging them.

According the above and based on the examples studied in this paper, the researcher assumes that although during the indicated 70 years period in Iran the translation norms significantly altered, still the trace of domestication can be seen in some cases. The reason of this trend may either be rooted in the marginal position of translated children's literature or the socio-cultural norms of the Persian society. 
However considering the nature of children's literature and the child audience, it is essential for translators of this genre that instead of escaping the new culture-bound elements and employing unnecessary domestication, do their best to apply the strategies, which not only help the nature of translation flourish facing the cultural diversity, but also give the children the chance of knowing and respecting the other cultures. This way the translated literature helps its child audiences to have a sharper insight about the world and diversity of cultures, customs and beliefs as well as attracting them to find out more about them.

\section{References}

Axiela, J. F. (1996). Culture-Specific Items in Translation Translation, Power, Subversion (pp. 52-78). Clevedon: Multilingual Matters.

Bassnett, S., \& Lefevere, A. (1998). Constructing cultures: Essays on literary translation. Clevedon: Multiingual Matters.

Bassnett, S. (2014). Translation. London \& New York: Routledge.

Fernandes, L. (2006). Translation of Names in Children's Fantasy Literature: Bringing the young reader into play. New Voices in Translation Studies, 2(2006), 44-57.

Hunt, P. (1997). Censorship and Children's Literature in Britain Now, or, the Return of Abigail. Children's literature in Education 28, 95-103.

Hunt, P. (2005). Introduction: The expanding world of children's literature studies. In p. Hunt (Ed.), understanding children's leterature (pp. 1-14). London \& New York: Routledge.

Lathey, G. (2006). Thr translation of children's literature: A reader. Clevedon: Multilingual Matters.

Lathey, G. (2016). Translating Children's Literature. London and New York: Routledge.

Lefevere, A. (1992a). Translation, culture, history. London: Routledge.

Knowles, M., \& Malmkjar, K. (1996). Language and Control in Children's Literature. London \& New York: Routledge.

McCulloch, F. (2011). Chidren's literature in context. London \& New York: Continuum.

Munday, J. (2012). Introducing Translation Studies: theories and applications. London \& New York: Routledge.

Naghmehabbaspour, B. (2013). Domestication and Foreignization in Translation of Children's Literature: A Textual Analysis. In A. P. et-al (Ed.), New Literacies: Reconstructing Language and Education (pp. 64-76). Newcastle: Cambridge Scholars Publishing.

Oittinen, R. (2000). Translating for children. NEW YORK \& LONDON GARLAND PUBLISHING, INC.

Oittinen, R. (2006). No Innocent act: On the ethics of translating for children. In J. V. Coillie \& W. P. Verschueren (Eds.), Children's literature in translation: Challenges and strategies. London \& New York: Routledge. 
O'sullivan, E. (2005). Comparative Children's Literature. London \& New York: Routledge.

Shavit, Z. (1981). Translation of chidren's literature as a functionof its position in the literary poelysystem. Poetics Today, 2(4), 171-179.

Shavit, Z. (1986). Translation of Children's literature: Poetics of Children's Literature. Athens and London: The University of Georgia Press.

Venuti, L. (1995). The translator's Invisibility: A History of Translation. London: Routledge.

Yamazaki, A. (2002). Why Change Names? On the Translation of Children's Books. Children's literature in Education 33: 53- 59.

\section{Copyrights}

Copyright for this article is retained by the author (s), with first publication rights granted to the journal.

This is an open-access article distributed under the terms and conditions of the Creative Commons Attribution license (http://creativecommons.org/licenses/by/4.0/). 